SHORT COMMUNICATION

\title{
Comparative Evaluation of the Efficacy of Herbal Regimen for the Treatment of Post-partum Anestrus in Water Buffaloes
}

\author{
Kancharla Jyothi ${ }^{1}$, Yeddula Venkata Pridhvidhar Reddy ${ }^{1}$, Kalubandi Sai Gunaranjan ${ }^{1}$, Thopireddy Nagendra \\ Reddy $^{2}$, Sunidhi ${ }^{3}$, Ravikanth Kotagiri ${ }^{3}$ and Bhaskar Ganguly ${ }^{3 *}$ \\ ${ }^{1}$ Department of Gynecology and Obstetrics, College of Veterinary Science, Proddatur, Andhra Pradesh, INDIA \\ ${ }^{2}$ Department of Veterinary Microbiology, College of Veterinary Science, Proddatur, Andhra Pradesh, INDIA \\ ${ }^{3}$ Research E Development Unit, Ayurvet Limited, Baddi, Himachal Pradesh, INDIA \\ *Corresponding author: B Ganguly; E-mail: clinical01@ayurvet.in
}

Received: 28 Jan., 2020

Revised: 02 May, 2020

Accepted: 13 May, 2020

\begin{abstract}
A study was undertaken to compare the efficacy of combinations of different brands of herbal uterine cleansers, estrus inducers and mineral supplements in the treatment of anestrus in water buffaloes. Thirty she-buffaloes with a history of anestrus were randomly assigned to either of five equal groups. Group T0 served as untreated control, Group T1 was treated with a combination of Exapar bolus (M/s Ayurvet Limited, India), Janova capsule (M/s Ayurvet Limited, India) and Mintrus caplet (M/s Ayurvet Limited, India). Group T2 was treated with AV/UTB/26 bolus (M/s Ayurvet Limited, India), AV/OIP/22 powder (M/s Ayurvet Limited, India) and Mintrus caplet. Group T3 was treated with a combination of Brands A, B and C. Group T4 was treated with a combination of Brands X, Y and Z. The best estrus response was recorded in the Group T2 and the highest conception rates in Groups T2 and T4. The time interval between treatment and onset of estrus was significantly lowest $(\mathrm{P}<0.05)$ in Group T1 as compared to the other groups.
\end{abstract}

Keywords: Exapar, Janova, Mintrus, anestrus, buffalo, herbal

Of all the domesticated animals, the buffalo has the greatest unexplored potential for the development of milk yield, meat production and work output (Jyothi et al., 2020). The buffalo plays a prominent role in rural economy, providing milk, meat and draft work-force (Hoffpauir, 1982). The increasing interest in buffalo rearing is primarily due to more desirable composition of buffalo milk in comparison to cow milk in terms of higher milk-fat content yet low cholesterol, higher total solids, SNF, proteins, calcium, phosphorus and calories per unit. Reproductive efficiency is the primary factor affecting productivity and is hampered by inherent late maturity, poor expression of estrus in summers, distinct seasonal reproductive patterns and prolonged inter-calving intervals in female buffalo (Singh et al., 2000). Anestrus, defined as a prolonged period of sexual quiescence (Agarwal et al., 2005), especially manifesting as post-parturient anestrus, is a major reproductive disorder in dairy animals (El-
Wishy, 2007). The present clinical trial was designed to compare the efficacy of some combinations of different brands of herbal preparations in post-partum anestrus in water buffaloes.

The present study was undertaken in and around Proddatur, Kadapa district, Andhra Pradesh. Thirty animals with a history of anestrus were identified and confirmed on the basis of clinical signs and per-rectal examination. Perrectal examination was performed at 10 days interval

How to cite this article: Jyothi, K., Reddy, Y.V.P., Gunaranjan, K.S., Reddy, T.N., Sunidhi, Kotagiri, R. and Ganguly, B. (2020). Comparative evaluation of the efficacy of herbal regimen for the treatment of postpartum anestrus in water buffaloes. J. Anim. Res., 10(3): 471-473.

Source of Support: This study was financially supported by M/s Ayurvet Limited; Conflict of Interest: Sunidhi, Ravikanth Kotagiri, and Bhaskar Ganguly are employees of M/s Ayurvet Limited, India. However, the nature of this employment did not influence the outcomes of the study in any manner. (a) 9 
beginning 90 days post-partum. The buffaloes were randomly allocated to either of five equal groups (Group T0-T4) and treated with different herbal regimens. Group T0 did not receive any treatment. Group T1 received a combination of ExaparTM bolus (M/s Ayurvet Limited, India)@ 4 boli/day orally for 5 days (days 1-5 of parturition), Janova ${ }^{\mathrm{TM}}$ capsule (M/s Ayurvet Limited, India)@ 3 cap/day for 2 days (days 6 and 7) and Mintrus ${ }^{\circledR}$ caplet (M/s Ayurvet Limited, India)@ 1 caplet daily for 20 days (days 0-20). Group T2 received treatment with a combination of AV/UTB/26 bolus (M/s Ayurvet Limited, India)@ 2 boli/day for 5 days (days 1-5 of parturition), AV/OIP/22 powder (M/s Ayurvet Limited, India) @ 200g/ day for two days (days 6 and 7) and Mintrus ${ }^{\circledR}$ caplet @ 1 caplet daily for 20 days (days 0-20). Group T3 was treated with a combination of Brand A@200 ml on the first day, followed by single $100 \mathrm{~mL}$ dose once daily for next 3 days, Brand B@3 cap/day for 2 days (days 6 and 7) and Brand C@ 1 tab daily for 20 days (days 0-20). Group T4 was treated with a combination of Brand X@200 mL on the first day, followed by $100 \mathrm{~mL}$ for 3 consecutive days (day 2-4 of parturition), Brand Y @ 2 boli once daily orally for 3 consecutive days (days 5-7) and Brand Z @ 1 caplet orally for 10 consecutive days. Parameters such as estrus response, estrus induction interval, conception rate, number of services per conception and nature of cervical discharge were studied.

The estrus response among the groups was recorded in the order T2 $(6$ of $6 ; 100 \%)>\mathrm{T} 4(5$ of $6 ; 83.33 \%)>\mathrm{T} 1=\mathrm{T} 3$ ( 4 of $6 ; 66.67 \%)>$ T0 (1 of $6 ; 16.67 \%)$. Similarly, the conception rate was recorded in the order $\mathrm{T} 2=\mathrm{T} 4$ (4 of $6 ; 66.67 \%)>\mathrm{T} 1=\mathrm{T} 3(2$ of $6 ; 33.33 \%)>\mathrm{T} 0(1$ of 6 ; $16.67 \%)$. The estrus induction interval was recorded to be shortest and significantly different $(\mathrm{P}<0.05)$ in the group $\mathrm{T} 1$, receiving treatment with a combination of Exapar, Janova and Mintrus ( $8.0 \pm 0.81$ days), as compared to the remaining groups $(\mathrm{T} 0=27.0 \pm 1.0$ days; $\mathrm{T} 2=27.33 \pm 0.45$ days; $\mathrm{T} 3=28.25 \pm 1.70$ days; $\mathrm{T} 4=22.6 \pm 0.92$ days $)$. The average number of services per conception was recorded to be 1 in groups T0, T1 and T2, 1.6 in group T4 and 2 in group T3. The number of animals showing clear mucus discharge at estrus was in the order $\mathrm{T} 1=\mathrm{T} 2=\mathrm{T} 4(66.66 \%)$ $>\mathrm{T} 3(50 \%)>\mathrm{T} 0(16.66 \%)$.

The combination of Exapar, Janova and Mintrus has previously also been shown to be efficacious in the management of different reproductive disorders in buffaloes (Hadiya et al., 2015). Citrullus colocynthis, a constituent ingredient of $\mathrm{AV} / \mathrm{OIP} / 22$, is a rich source of flavonoids (Benariba et al., 2013), isovitexin (Akhzari et al., 2015), cucurbitacin (Hatam et al., 1989) and caffeic acid (Shokrzadeh et al., 2013). The improvement in the estrus response may be attributed to caffeic acid which is known to inhibit nuclear factor kappa B (Akyol et al., 2015), a transcription factor which brings about changes in mRNA synthesis and has a negative effect on reproductive performance (Manimaran et al., 2016). The improved estrus response may have also been brought about by the presence of flavonoids which are known to possess antioxidant property (Pietta, 2000) and improve reproductive health (Lessera et al., 2015). Presence of isovitexin may also have played a significant role in accentuating the estrus response as it is known to possess free radical scavenging activity (Khole et al., 2016) and neutralize the peroxy free radicals that hamper the proper functioning of the reproductive organs (Agrawal et al., 2005). Zingiber officinale, also a constituent ingredient of $\mathrm{AV} / \mathrm{OIP} / 22$, is known to possess anti-oxidant property (Ghasemzadeh et al., 2010) and may aid in onset of ovulation in cows suffering from post-partum anestrus.

It could be concluded that Exapar-Janova-Mintrus protocol (Group T1) was effective at inducing estrus within short interval after initiation of treatment in water buffaloes suffering with post-partum anestrus and AV/UTB/26-AV/ OIP/22-Mintrus protocol (Group T2) was found to be effective in giving optimum conception rate and estrus response in post-partum anestrus buffaloes.

\section{REFERENCES}

Agarwal, A., Gupta, S. and Sharma, R.K. 2005. Role of oxidative stress in female reproduction. Reprod. Biol. Endocrinol., 3(1): 28.

Agarwal, S.K., Singh, S.K. and Rajkumar, R. 2005. Reproductive disorders and their management in cattle and buffalo: A review. Ind. J. Anim. Sci., 75(7): 858.

Akhzari, M., Mirghiasi, S.M., Vassaf, M., Bidgoli, M.S.M. and Tari, Z.S. 2015. The effect of Citrullus colocynthis on the reduction of inflammatory agents in osteoarthritis. Mol. Biol., 4: 147.

Akyol, S., Akbas, A., Butun, I., Toktas, M., Ozyurt, H., Sahin, S. and Akyol, O. 2015. Caffeic acid phenethyl ester as a remedial agent for reproductive functions and oxidative stress-based pathologies of gonads. J. Intercultural Ethnopharmacol., 4(2): 187 
Benariba, N., Djaziri, R., Bellakhdar, W., Belkacem, N., Kadiata, M., Malaisse, W.J. and Sener, A. 2013. Phytochemical screening and free radical scavenging activity of Citrullus colocynthis seeds extracts. Asian Pacific J. Tropical Biomed., 3(1): 35-40.

El-Wishy, A.B. 2007. The postpartum buffalo: II. Acyclicity and anestrus. Ani. Reprod. Sci., 97(3-4): 216-236.

Ghasemzadeh, A., Jaafar, H.Z. and Rahmat, A. 2010. Antioxidant activities, total phenolics and flavonoids content in two varieties of Malaysia young ginger (Zingiber officinale Roscoe). Molecules, 15(6): 4324-4333.

Hadiya, K., Ravikanth, K., Adarsh and Reothia, A. 2015. Efficacy of Exapar, Janova and Mintrus (EJM) in the treatment of various reproductive disorders in Jaffrabadi buffaloes. Int. J. Adv. Res., 3(9): 1213-1216.

Hatam, N.A., Whiting, D.A. and Yousif, N.J. 1989. Cucurbitacin glycosides from Citrullus colocynthis. Phytochem., 28(4): 1268-1271.

Hoffpauir, R. 1982. The water buffalo: India's other bovine. Anthropos, 77(1-2): 215-238.

Jyothi, K., Reddy, Y.V.P., Gunaranjan, K.S., Reddy, T.N., Sunidhi., Ravikanth, K. and Ganguly, B. 2020. Comparative Evaluation of the Efficacy of some Comprehensive Herbal Regimen for the Treatment of Repeat Breeding in Water Buffaloes. Int. J. Curr. Micro. App. Sci., 9(1): 2116-2121.
Khole, S., Panat, N.A., Suryawanshi, P., Chatterjee, S., Devasagayam, T.P.A. and Ghaskadbi, S. 2016. Comprehensive Assessment of Antioxidant Activities of Apigenin Isomers: Vitexin and Isovitexin. Free Radic. Antioxidants, 6(2): 155166.

Lessera, N.R., Carl, L. and Lanoue, K.L. 2015. Reproductive and developmental outcomes and influence on maternal and offspring tissue mineral concentrations, of (-)-epicatechin, $(+)$-catechin and rutin ingestion prior to and during pregnancy and lactation in C57BL/6J. Toxicol. Rep., 2: 443-449.

Manimaran, A., Kumaresan, A., Jeyakumar, S., Mohanty, T.K., Sejian, V., Kumar, N., Sreela, L., Prakash, M.A., Mooventhan, P., Anantharaj, A. and Das, D.N. 2016. Potential of acute phase proteins as predictor of postpartum uterine infections during transition period and its regulatory mechanism in dairy cattle. Vet. World, 9(1): 91-100.

Pietta, P.G. 2000. Flavonoids as antioxidants. J. Nat. Prod., 63(7): 1035-1042.

Shokrzadeh, M., Chabra, A., Naghshvar, F. and Ahmadi, A. 2013. The mitigating effect of Citrullus colocynthis (L.) fruit extract against genotoxicity induced by cyclophosphamide in mice bone marrow cells. The Scientific World J., 2013.

Singh, J., Nanda, A.S. and Adams, G.P. 2000. The reproductive pattern and efficiency of female buffaloes. Ani. Reprod. Sci., 60: $593-604$. 
